\title{
STRATEGI PEMERINTAH INDONESIA DALAM \\ PENYELESAIAN KASUS AMBALAT
}

\author{
Rizki Kesuma \\ RizkyKesuma4@gmail.com
}

\begin{abstract}
ABSTRAK
Sengketa Perbatasan antara Indonesia dan Malaysia sering kali terjadi, terutama di kawasan perbatasan maritim. Sengketa Ambalat di laut Sulawesi merupakan salah satu contoh sengketa perbatasan maritim yang belum selesai hingga saat ini. Sengketa Ambalat mencuat sedikit banyak adalah pengaruh atas kemenangan Malaysia atas Sipadan dan Ligitan, dimana hakim Mahkamah Internasional memberikan kemenangan atas Sipadan dan Ligitan dengan alasan penguasaan efektif (effective occupancy) di wilayah tersebut. Kemenangan Malaysia atas Sipadan dan Ligitan, membuat Malaysia semakin berani mengklaim kawasan maritim lain di Indonesia,dengan peta unilateral 1979 yang dibuat oleh Malaysia, mereka kembali mengklaim kawasan lain di Indonesia, salah satunya yaitu Ambalat.Ambalat yang ditenggarai memiliki kandungan minyak dan gas bumi yang berlimpah merupakan salah satu tujuan Malaysia untuk menguasai Ambalat. Pemerintah Indonesia tentu tidak tinggal diam dan segera mengambil langkah-langkah untuk menyelesaiakan permasalahan ini,pemerintah Indonesia melakukan beberpa pendekatan seperti pendekatan secara hukum,politik,dan kedekatan wilayah untuk mengklaim Ambalat sebagai bagian dari wilayah Indonesia, dalam penelitian ini penulis menggunakan metodologi penelitian kualitatif dimana menurut Bodgan dan Taylor dalam Lexy J. Moleong merupakan prosedur penelitian yang menghasilkan data secara deskriptif berupa kata-kata tertulis atau lisan dari orang-orang dan perilaku yang dapat diamati. Dalam penelitian ini digunakan data-data kualitataif yang diambil dari buku-buku, maupun laporan dari kedutaan besar Indonesia serta didukung oleh beberapa data
\end{abstract}


yang didapat seperti jurnal ilmiah dari lembaga penelitian Indonesia (LIPI) dan beberapa sumber dari internet untuk melengkapai penelitian ini.

Kata kunci : Ambalat, Indonesia, Malaysia, Sengketa, Strategi.

\begin{abstract}
Border dispute between Indonesia and Malaysia is often occurs, especially in the area of maritim border. Ambalat in Sulawesi Sea is one example of the maritime border dispute which has not been finished until now. Ambalat is sticking out a little more influence on Malaysian victory over Sipadan and Ligitan, which the International Court Jjustices gave victory to Malaysia over Sipadan and Ligitan with effective control reasons (effective occupancy) in the region. Malaysia won over Sipadan and Ligitan causing Malaysia gets more courage to claim another Indonesia's maritime area. They reclaimed areas in Indonesia with their unilateral map made by Malaysia in 1979 and one of the claimed area is Ambalat. Ambalat which is allegedly contains oil and gas abundance is one of Malaysia's goal to own Ambalat. Indonesian government would not remain silent and take immediate steps to solve this problem, Indonesian government made an approach such as legally approach, politically, and the proximity of the area to claim Ambalat as part of Indonesian territory. In this research, the authors is using a qualitative research methodology by Bodgan and Taylor in Lexy J. Moleong with a research procedure that produces descriptive data in the form of written words or spoken words of the people and behaviors that can be observed. This research is using qulitative data taken from the books, as well as reports from the Indonesian Embassies and supported by some datas that obtained from scientific journals such as from Research Institutes of Indonesia (LIPI) and some internet resources for completed the research.
\end{abstract}




\section{Global Insigint Journal}

Vol 03, No. 01 Oktober - Maret 2018

ISSN 2541-318X

Keywords : Ambalat, Dispute, Indonesia, Malaysia, Strategic. 


\section{PENDAHULUAN}

\subsection{Latar Belakang Masalah}

Indonesia dan Malaysia adalah dua negara yang terletak di Asia Tenggara, kedua negara dikenal memiliki kesamaan dalam historis dan juga geografis, sehingga disebut sebagai negara Collective Identity atau Identitas Bersama atau sama halnya dengan negara serumpun, Menurut Menteri Pertahanan Malaysia, Sanusi Djuned dan mantan rektor Universitas Islam Internasional Malaysia "Hampir 80 persen etnis Melayu adalah keturunan Indonesia". 1 Kata identitas serumpun ini juga muncul karena Indonesia memiliki kesamaan dalam akar- akar budaya, agama dan sejarah- sejarah kerajaan. Sebelum terbentuknya kemerdekaan masing-masing negara, Menurut Khoridatul Anissa, "Kesultanan-kesultanan Melayu di Sumatera dan kesultanan-kesultanan di Semenanjung Malaysia memang sering melakukan interaksi dalam hal kerjasama." ${ }^{2}$

Hubungan antar kedua kesultanan ini berjalan cukup baik dan lancar, namun semenjak masuknya para penjajah dari negara asing dalam sejarah kerajaan dan kesultanan di wilayah Malaya dan Nusantara inilah yang merubah keselarasan hubungan antar bangsa Melayu dan secara tidak langsung kawasan yang berada di Malaya dan Nusantara diatur oleh para penjajah tersebut sesuai dengan kehendaknya masing-masing. Wilayah ini dibagi-bagi kepada Inggris dan Belanda. Dimana Inggris menguasai wilayah yang sekarang disebut dengan Malaysia sedangkan Belanda menguasai wilayah sekarang disebut Indonesia, hasil ini merupakan kesepakatan yang tertuang dalam Traktat London (Treaty of London 1824) antar kedua belah pihak.

Perjanjian tersebut disahkan oleh Inggris pada tahun 30 April 1824 dan Belanda pada 02 Juni 1824. Kemudian pada tahun 1939, Belanda mengeluarkan peta yang disebut dengan peta Territorial Zee en Maritieme Kringen Ordonanti

\footnotetext{
${ }^{1}$ Wawan H. Purwanto, “Serumpun, Kerap Tak Rukun”,Panas Dingin Hubungan IndonesiaMalaysia, Jakarta: CMB Press, 2010, hal.61.

${ }^{2}$ Khoridatul, Annisa, ” Rumpun Melayu : Kesamaan Budaya?”, Malaysia Macan Asia: Ekonomi, Politik, Sosial - Budaya, dan Dinamika Hubungannya dengan Indonesia, Jogjakarta: Garasi, 2009, hal. 174.
} 


\section{Global Insight Journal}

Vol 03, No. 01

Oktober - Maret 2018

ISSN 2541-318X

(TZMKO) atau dalam bahasa Indonesia disebut dengan Ordonansi Laut Territorial dan Lingkungan-Lingkungan Maritim. Menurut Dino Patti Djalal dalam bukunya menerangkan bahwa peta TZMKO 1939 menetapkan pulau-pulau di wilayah Nusantara (Indonesia) dipisahkan oleh laut di sekelilingnya dan setiap pulau hanya mempunyai laut di sekeliling sejauh 3 mil diukur dari garis air pasang surut, berikut adalah penjelasan dari Dino Patti Djalal :

"Insofar as the maritim boundary is concerned, Indonesia's territorial arrangement was now administered under The Territorial Zee en Maritieme Kringen Ordonnantie 1939, a colonial ordinance which stipulated that the country soverignity extended three miles from the lowwater mark". 3

Peta ini membuat kapal asing boleh dengan bebas melayari laut yang memisahkan pulau-pulau tersebut, hal ini tentu membawa dampak negatif bagi perekonomian Indonesia dan juga membahayakan kesatuan Negara Republik Indonesia. Berikut adalah gambar peta yang dibuat oleh Belanda pada tahun 1939 yang dikenal dengan peta TZMKO :

Gambar 1

Peta Territorial Zee Maritieme Kringen Ordonanti (TZMKO) Belanda

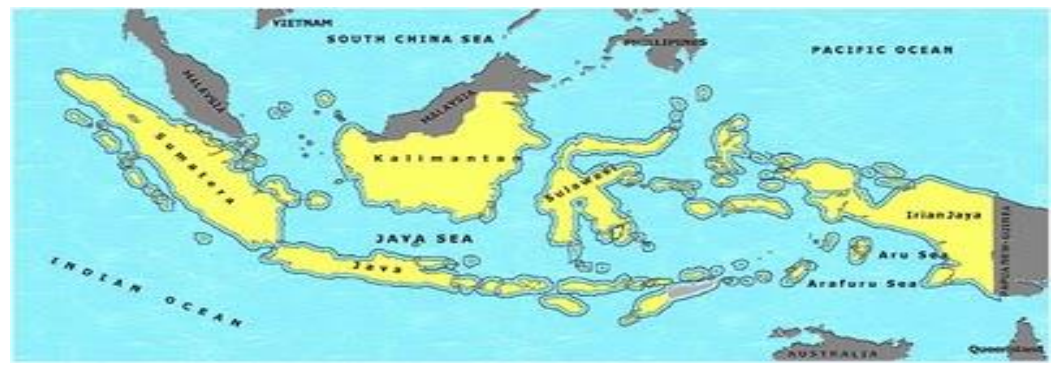

Sumber : Buku Wawasan Nusantara

Indonesia Merdeka pada 17 agustus 1945, pada saat itu peraturan wilayah Indonesia masih berlaku peraturan Belanda yang ditetapkan dalam TZMKO dimana lebar laut territorial Indonesia hanya 3 mil diukur dari garis air pasang

\footnotetext{
${ }^{3}$ Dino Patti Djalal, "The Colonial Maritim Boundary", The Geopolitics Of Indonesia's Maritim Territorial Policy, Jakarta:CSIS, 1996, hal.19
} 


\section{Global Insigint Journal}

Vol 03, No. 01

Oktober - Maret 2018

ISSN 2541-318X

surut masing-masing pulau Indonesia, dikarenakan hal ini dapat merugikan Indonesia maka Indonesia kembali memperjuangkan NKRI sebagai negara kepulauan yang mengacu pada Deklarasi Juanda 1957 dimana Indonesia menganut prinsip-prinsip negara kepulauan (Archipelagic State) dan setelah lamanya berjuang akhirnya konsep negara kepulauan tersebut di terima di Konvensi Hukum Laut Internasional atau UNCLOS (United Nations Conventions on The Law Of The Sea) pada tahun 1982 yang diadakan di Montego Bay,Jamaica. Seperti yang dikatakan Mantan Pangkopkamtib Laksamana TNI (Purn) Soedomo, "Dalam keputusan UNCLOS 1982, United Nations on Law of the Sea itu diakui bahwa Indonesia adalah negara kepulauan. ${ }^{64}$ Menurut I Made Andi Arsana Indonesia sendiri mempunyai wilayah laut yang berbatasan dengan 10 negara yaitu India, Malaysia, Singapura, Thailand, Vietnam, Filipina, Republik Palau Australia, Timor Leste dan Papua Nugini. ${ }^{5}$ Namun permasalahan perbatasan wilayah Indonesia yang paling krusial adalah dengan Malaysia. Berikut adalah gambar yang mengilustrasikan Indonesia dan kesepuluh negara yang berbatasan dengan Indonesia.

\section{Gambar 2}

Indonesia dan sepuluh negara tetangga

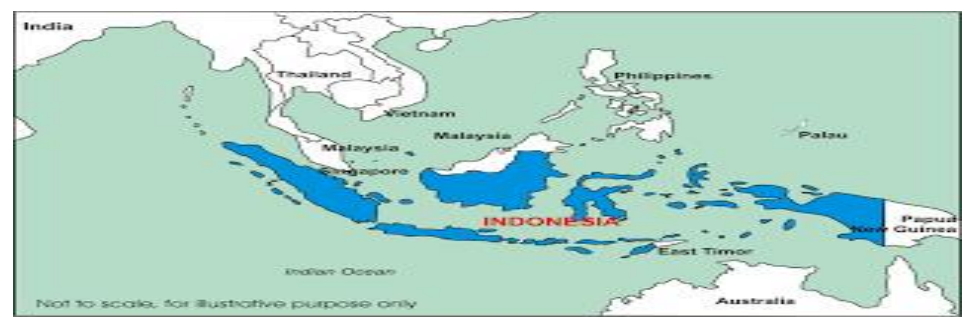

Sumber : Buku Batas Maritim Antar Negara

Indonesia dan Malaysia mempunyai masalah persengketaan yang cukup rumit, konflik kedua negara terjadi mulai dari masalah perbatasan darat,

4 Mirza Gemilang, "Hari Nusantara 2011 : Negara kepulauan diakui Dunia",harian KOMPASIANA, diakses dari http://hankam.kompasiana.com/2011/09/12/hari-nusantara-2011negara-kepulauan-diakui-dunia-395067.html, pada tanggal 17 Maret 2013.

${ }^{5}$ I Made Andi Arsana, "Mengenal Batas Maritim Indonesia", Batas Maritim Antarnegara, Yogyakarta:Gadjah Mada University Press, 2007, hal.138. 
pembalakan liar, Tenaga Kerja Indonesia (TKI), hingga masalah perbatasan laut, khusus untuk permasalahan perbatasan laut Indonesia, cukup banyak sengketa yang terjadi diantara kedua negara ini salah satunya adalah tumpang tindih di selat Malaka yang menjadi jalur perdangangan internasional yg sangat ramai.

Selat Malaka merupakan salah satu kasus perbatasan laut antara Indonesia dan Malaysia, kedua negara ini mempunyai beberapa kasus lagi mengenai wilayah perbatasan yaitu seperti Kasus Sipadan dan Ligitan, kasus yang mencuat semenjak tahun 1967, dimana pada tahun ini diadakan pertemuan teknis mengenai hukum laut dan akhirnya kedua negara bersepakat untuk menjadikan Sipadan dan Ligitan sebagai status quo, dan pada tahum 1969 Indonesia dan Malaysia melakukan penandatanganan kesepakatan yang disebut dengan Perjanjian Tapal Batas Kontinental 1969 dan diratifikasi pada 7 november 1969. Namun pada tahun 1979 menurut Syamsumar Dam Malaysia membuat peta secara unilateral dan memasukan Sipadan danLigitan sebagai wilayah Malaysia dan Pedra Blanca milik Singapore sebagai bagian dari wilayah Malaysia dan tentunya peta ini tidak diakui oleh Indonesia dan Singapore. ${ }^{6}$

Mulai dari hal ini, karena tidak menemui kesepakatan setelah diadakan beberapa kali pertemuan bilateral dan karena segan untuk membawa permasalahan ini ke tingkat ASEAN, kedua negara ini memilih untuk membawa kasus sengketa wilayah ini ke Mahkamah Internasional atau ICJ (International Court Of Justice) pada tahun 1998. Namun sayangnya Indonesia kalah dalam perebutan wilayah ini dengan 16 dukungan suara hakim kepada Malaysia dan 1 dukungan suara hakim terhadap Indonesia sehingga pada Desember 2002 Sipadan dan Ligitan resmi jatuh menjadi bagian wilayah Malaysia. Menurut I Made Andi Arsana Hakim Makhamah Internasional menimbang hal ini dari perspektif effectivity (tanpa memutuskan pada pertanyaan dari perairan teritorial dan batasbatas maritim), yaitu pemerintah Inggris (penjajah Malaysia) telah melakukan tindakan administratif secara nyata berupa penerbitan ordonansi perlindungan

${ }^{6}$ Syamsumar Dam, "Perbatasan Maritim RI-Malaysia”, Politik Kelautan, Jakarta:Bumi Aksara, 2010, hal.59. 
satwa burung, pungutan pajak terhadap pengumpulan telur penyu sejak tahun 1930, dan operasi mercusuar sejak 1960-an. ${ }^{7}$

Kekalahan yang diterima Indonesia pasca kemenangan Malaysia atas Sipadan dan Ligitan membawa kekecewaan yang sangat besar bagi Indonesia, setelah selang beberapa tahun pasca sengketa Sipadan dan Ligitan, terjadi kembali sengketa mengenai Blok Ambalat. Menurut data Ditjen Migas Departemen Energi dan Sumber Daya Mineral, "Kawasan ini memang mempunyai kandungan minyak yang kaya, di wilayah perairan timur Kalimantan kandungan minyak hingga mencapai 700 juta hingga satu miliar barel, sementara kandungan gas-nya diperkirakan lebih dari 40 triliun kaki kubik". 8

Malaysia kembali melakukan klaim sepihak dengan berdasarkan kepada Peta Nasional Malaysia (Peta Pentas Benua) tahun 1979. Peta ini merupakan peta unilateral yang dibuat Malaysia untuk mengklaim wilayah perbatasan Indonesia. Peta ini tidak diakui oleh UNCLOS 1982 karena tidak memiliki dasar atau acuan hukum. Peta Nasional Malaysia ini secara sepihak memajukan koordinat $4^{\circ} 10^{\prime}$ arah utara melewati Pulau Sebatik. ${ }^{9}$ Menurut UNCLOS 1982 pasal 16 ayat 2 disebutkan bahwa syarat utama penggunaan sebuah peta dan daftar koordinat geografis suatu negara adalah, "Negara pantai harus memberikan pengumuman sebagaimana mestinya mengenai atau daftar koordinat geografis tersebut dan mendepositkan satu salinan atau turunan setiap atau daftar tersebut kepada Sekretaris Jendral Perserikatan Bangsa - Bangsa." ${ }^{10}$ Setiap negara yang membuat suatu peta wilayah diwajibkan untuk mengumumkan pada negara tetangganya yang berbatasan langsung dan memberitahukan kepada PBB. Namun Malaysia tidak melakukan hal tersebut, Malaysia tetap bersikeras dengan penggunaan Peta Nasional Malaysia 1979 sebagai dasar klaim atas Ambalat dan kawasan teritorial lainnya. Ini artinya bahwa peta 1979 merupakan peta yang tidak mempunyai implikasi hukum tetapi mempunyai implikasi politis.

\footnotetext{
${ }^{7}$ I Made Andi Arsana, op.cit., hal.157.

${ }^{8}$ Teuku Rezahsyah, Op.Cit.,hal. 96.

9 Wikipedia," Ambalat", diakses dari http://id.wiki pedia.org/wiki/Ambalat. pada tanggal 12 Januari 2013.

${ }^{10}$ Khoridatul Annisa, Op.Cit., hal. 198.
} 


\section{Global Insigint Journal}

Dari uraian diatas penulis lemudian akan meneliti Bagaimana strategi pemerintah Indonesia dalam penyelesaian kasus Ambalat ketika tidak membawa kasus tersebut ke ICJ ?

\section{PEMBAHASAN}

\section{Awal Persengketaan Ambalat}

Permasalahan perbatasan antara Indonesia Malaysia dimulai pada tahun 1967, Dimana pada tahun tersebut diadakan pertemuan teknis hukum laut yang membahas tentang batas wilayah, dalam pertemuan ini ternyata Indonesia dan Malaysia memasukan Sipadan Ligitan sebagai bagian dari wilayah kedua negara tersebut dan akhirnya Indonesia dan Malaysia bersepakat membuat Sipadan dan Ligitan sebagai Status Quo. Namun dalam keadaan yang telah disepakati oleh kedua negara ini ternyata ditanggapi berbeda oleh Malaysia, Malaysia berpikir selama Sipadan dan Ligitan dalam status quo hal ini berarti Sipadan dan Ligitan masih menjadi hak milik mereka dan Malaysia pun membangun resort tanpa sepengetahuan Indonesia, mereka membangun resort di atas Sipadan, pulau yang mempunyai luas $4 \mathrm{~km}^{2}$.

Pembangunan tersebut akhirnya diketahui oleh Indonesia dari Menlu Ali Alatas pada tanggal 5 Juni 1991, dan pada saat itu pemerintah Indonesia langsung meminta Malaysia untuk menghentikan kegiatannya dalam pembangunan resort di kawasan Sipadan dan Ligitan namun sayangnya protes tersebut diabaikan dan akhirnya kedua negara sepakat membawa masalah tersebut ke ICJ pada 19972002, kasus Sipadan Ligitan dimenangkan kepada Malaysia oleh ICJ dengan alasan Continuous Presence, Effective Occupation (termasuk administrasi pemerintahan) dan Ecology Preservation, permasalahan pokok yang dihadapi oleh 
kedua negara ini yaitu garis batas landas kontinen yang justru tidak dibawa atau dibahas dalam sengketa ini. ${ }^{11}$

Mengenal lebih jauh tentang Ambalat, Ambalat sendiri bukanlah sebuah pulau melainkan sebuah kawasan laut seluas 15.235 kilometer persegi yang terletak di Laut Sulawesi atau Selat Makassar dan berada di dekat perpanjangan perbatasan darat antara Sabah, Malaysia, kalimantan Timur,Indonesia.Ambalat ditenggarai memiliki sumber daya Alam yang dapat digunakan hingga 30 tahun kedepan.

Kedua negara ini mempunyai sebutan masing-masing bagi Ambalat, Indonesia menyebut kawasan ini dengan Blok Ambalat dan East Ambalat sedangakan Malaysia menyebutnya dengan ND 6 (Blok Y) dan ND 7 (Blok Z) juga lebih terkenal dengan sebutan Blok YZ Permulaan sengketa terjadi semenjak Malaysia secara sepihak memberikan konsesi minyak kepada perusahaan asing yaitu Shell, perusahaan minyak milik Belanda dan Inggris melalui perusahan minyak Malaysia yaitu Petronas Carigali.

Menurut Terry Subagja sebelum Malaysia melakukan konsesi minyak secara sepihak kepada Shell, Indonesia telah lebih dulu mengelola dan memberikan konsesi minyak kepada perusahaan asing semenjak tahun 1960. Konsesi minyak yang dilakukan indonesia di Laut Sulawesi terutama di kawasan Blok Ambalat tidak pernah mendapatkan protes dari Malaysia walaupun kawasan tempat konsesi minyak tersebut memasuki bagian wilayah Peta Pentas Benua atau Peta Nasional 1979 menurut Malaysia. Malaysia mulai mengadakan protes mengenai konsesi ini pasca kemenangan Malaysia atas wilayah Sipadan dan Ligitan dan puncaknya pada tahun 2005 dimana Malaysia memberikan hak konsesi minyak kepada perusahaan asing asal Belanda yaitu Shell.

\section{Klaim Kewilayahan atas Ambalat dari Kedua Negara}

Sumber daya alam berupa minyak dan gas bumi selalu menjadi perhatian setiap negara untuk dikuasai, dengan menguasai wilayah yang banyak

\footnotetext{
${ }^{11}$ Syamsumar Dam, Op.Cit., hal.52
} 
mengandung "emas hitam" ini maka dianggap dapat membawa keuntungan besar bagi perekonomian suatu negara. Sikap ingin menguasai inilah yang sering membuat suatu negara terlibat sengketa perbatasan terhadap negara lain, sama halnya dengan Indonesia dan Malaysia, sengketa perbatasan yang terjadi antar kedua negara ini cukup banyak dan beresikomulai dari sengketa selat Malaka, Sipadan Ligitan dan yang terjadi hingga saat ini yaitu klaim atas Ambalat. Kedua negara bersikeras memasukkan Ambalat sebagai bagian dari wilayahnya dan dalam skripsi ini penulis menjelaskan klaim atas Ambalat dari perspektif Indonesia dan Malaysia

\section{Klaim dari Perspektif Indonesia}

Indonesia mempunyai dasar dalam mengklaim Ambalat yaitu berdasarkan UNCLOS 1982 dimana Indonesia telah resmi diakui sebagai negara kepulauan, Dengan berlakunya UNCLOS 1982 maka UNCLOS 1982 berhak mengatur yurisdiksi maritim yang dapat diklaim oleh negara kepulauan, lebih lanjut dalam UNCLOS 1982 yurisdiksi maritim meliputi "zona-zona tertentu yaitu laut territorial (territorial sea) sejauh 12 mil laut, zona tambahan (contiguous zone) sejauh 24 mil laut, Zona Ekonomi Ekslusif (Exclusive Economic Zone) sejauh 200 mil laut dan landas kontinen (Continental Shelf) hingga $350 \mathrm{M}$ atau lebih."12 Jika dikaitkan dengan konflik Ambalat,maka dalam penarikan garis pangkal Indonesia dapat dilakukan dengan penarikan garis pangkal lurus atau straight baseline, penarikan garis pangkal lurus ini memperbolehkan Indonesia untuk menarik garis pangkal dari pulau terluar indonesia dan untuk mengukur laut teritorial dapat menggunakan garis pangkal lurus ini.

Setelah kehilangan Sipadan dan Ligitan, Indonesia menarik garis pangkal dari Karang Unarang dan penarikan garis dasar menggunakan Karang Unarang diperbolehkan bila menurut UNCLOS 1982 dan hal ini yang dijadikan klaim oleh Indonesia dalam kasus Ambalat. Menurut Khoridatul Anissa dalam UNCLOS 1982 dijelaskan bahwa:

${ }^{12}$ I Made Andi Arsana, Op.Cit. ,hal.8. 
"Selain Indonesia berhak untuk menarik garis pangkal dari Karang Unarang hingga 12 mil laut, Indonesia juga dapat mengukur hingga sejauh 200mil dan Ambalat yang terletak pada posisi 03039'LU, $118^{0} 22^{\prime} 00^{\prime \prime} \mathrm{BT}$, masih terletak 27 mil laut dari wilayah Indonesia yang berarti Ambalat terletak diwilayah landas Kontinen Indonesia, Ambalat juga merupakan kelanjutan alamiahdari wilayah Kalimantan Timur sehingga Indonesia berhak untuk menggunakan landas kontinen."13

\section{Klaim dari Perspektif Malaysia}

Malaysia membuat peta secara unilateral yang disebut dengan Peta Nasional 1979, peta ini ternyata memasukan kawasan Ambalat sebagai bagian wilayah Malaysia dengan memajukan koordinat $4^{\circ} 10^{\prime}$ arah utara melewati Pulau Sebatik. Pemasukan Ambalat dalam Peta unilateral yang dibuat Malaysia telah menyalahi aturan UNCLOS 1982 yang sudah ditandatangani kedua negara, dalam UNCLOS 1982 jelas disebutkan bahwa posisi kedudukan Indonesia dan Malaysia berbeda, Indonesia sebagai negara kepulauan (Archipelagic State) sedangkan Malaysia hanya sebagai negara pantai biasa (coastal state) ${ }^{14}$, penetapan garis dasar (garis pangkal) kedua negara pun berbeda dimana negara pantai seperti Malaysia hanya berhak mempergunakan garis dasar biasa. Hal ini bermakna bahwa Malaysia hanya bisa menarik garis pangkal 12 mil saja disepanjang pantainya yaitu Sabah dan tidak dapat menarik garis pangkal dari pulau-pulau terluar Malaysia yaitu Sipadan dan Ligitan. Malaysia menggunakan Sipadan dan Ligitan sebagai acuan untuk memasuki wilayah Indonesia, berikut adalah penjelasakan menurut Khoridatul Anissa tentang penggunaan Sipadan dan Ligitan oleh Malaysia :

"Malaysia menggunakan Sipadan dan Ligitan untuk mengukur laut territorial hingga Zona ekonomi Ekslusifnya dan dengan acuan ini Malaysia membuat klaim batas wilayah hingga jauh masuk kedalam wilayah Indonesia yaitu kawasan konsesi Ambalat, Malaysia pun

\footnotetext{
${ }^{13}$ Khoridatul Anissa, Op.Cit., hal.204.

${ }^{14}$ Teuku Rezahsyah, Op.Cit., hal 102.
} 


\section{Global Insigint Journal}

mempunyai argument berdasarkan UNCLOS 1982 pasal 121 ayat 2 yang berbunyi 'The Territorial Sea, the exclusive economic zone and the continental shelf of an Island are determined in accordance with the provisions of this convention applicable to other land territory' yang diartikan bahwa menurut Malaysia setiap pulau berhak mempunyai laut territorial, Zona Ekonomi Ekslusif dan landas kontinen sendiri." 15

Jika berdasarkan peraturan UNCLOS diatas adalah benar bahwa pulau berhak memiliki laut territorial sendiri namun yang perlu diingat bahwa Malaysia adalah negara pantai biasa dan tidak bisa menggunakan hak-hak yang berlaku pada negara kepualuan yaitu menarik garis pangkal dari pulau-pulau terluar. Sehingga jika melihat klaim yang dibuat Malaysia berdasarkan Peta unilateral 1979 tersebut tentu tidak dapat dijadikan acuan hukum, lebih lanjut Khoridatul Anissa menjelaskan bahwa terdapat 2 syarat dalam penggunaan peta dan daftar koordinat geografis suatu negara menurut UNCLOS 1982 pasak 16 ayat 2 dimana suatu negara wajib mengumunkan terlebih dahulu kepada seluruh negara di dunia dan kemudian mendepositkan satu turunan atau salinan ke Sekretaris Jendral PBB. ${ }^{16}$ Namun Malaysia tidak memenuhi dua syarat tersebut sehingga dapat disebut bahwa peta 1979 tidak memiliki implikasi hukum melainkan Implikasi politis dan merupakan usaha Malaysia untuk memperluas wilayahnya. Disimpulkan dalam UNCLOS 1982 Indonesia dan Malaysia berbeda dalam penarikan garis pangkal untuk mengukur batas laut teritorial namun kedua negara tetap berhak menarik garis landas kontinen dan ZEE yang berbeda hanya dari mana garis pangkal akan ditarik.

\section{Kepentingan Nasional Indonesia Terhadap Wilayah Ambalat}

Kepentingan nasional terdiri atas kepentingan ideologis, seperti dalam konflik super power pada era perang dingin, kepentingan strategis seperti nampak dalam perebutan wilayah pengaruh super power di berbagai kawasan, sedangkan

\footnotetext{
${ }^{15}$ Khoridatul Anissa, Op.Cit., hal.197.

${ }^{16}$ Ibid.,hal.198.
} 


\section{Global Insigint Journal}

kepentingan pragmatis lebih terkait dengan kalkulasi ekonomi yang diperebutkan, seperti potensi sumberdaya alam di suatu wilayah. Dalam hal ini akan dibahas dua kepentingan yang terkait dengan konflik ambalat, yaitu kepentingan strategis dan pragmatis.

\section{Kepentingan Strategis Indonesia}

SDA merupakan hal yang banyak diperebutkan oleh setiap negara, karena SDA diperhitungkan dapat meningkatkan perekonomian suatu negara dan mensejahterahkan masyarakat tersebut. Diantara masalah SDA yang terdapat di daratan dan kawasan maritim, kawasan maritim mempunyai resiko yang lebih tinggi dan penyelesaian yang cukup rumit karena menyangkut batas wilayah suatu negara.Indonesia adalah salah satu negara yang mempunyai cukup banyak cadangan minyak dan gas bumi. Menurut Kholid Syeirazi tersebar di seluruh pulau Indonesia, berikut adalah pendapat dari kholid syeirazi mengenai cekungan minyak di Indonesia.

"Cekungan minyak di Indonesia banyak terdapat di Pulau Jawa, bagian timur Kalimantan dan Sumatera, daerah kepala burung Papua, serta dibagian Seram, sementara cadangan gas bumi tersebar diseluruh Indonesia dan yang terbesar yaitu di pulau Natuna, Kalimantan Timur, dan Irian Jaya, selain itu juga terdapat di kawasan seperti Aceh, Sumatera Utara, Jambi, Sumatera Selatan, Jawa Barat dan Sulawesi. ${ }^{17}$

Perusahaan asing banyak masuk ke Indonesia semenjak diciptakannya perundang-undangan pada zaman Hindia Belanda yang disebut dengan Indische Minjwet 1899 beleid. Pertambangan yang terdapat di Indonesia menjadi perhatian utama negara besar hal ini tampak ketika diciptakannnya UU NO 22 tahun 2001 tentang Minyak dan gas Bumi, UU ini tercipta akibat perturan reformasi yang ditetapkan oleh IMF dalam sektor energi, Indonesia meminta bantuan IMF untuk

\footnotetext{
${ }^{17}$ M Kholid Syeirazi, "Tata Kelola Migas Indomesia", Di Bawah Bendera Asing, Jakarta:Pustaka, 2009 , hal.50.
} 
mengatasi krisis ekonomi yang terjadi di Indonesia dan IMF bersedia membantu dengan persyaratan seperti yang disebutkan diatas. ${ }^{18}$

Semenjak Migas diketahui sebagai sumber energi yang strategis dan takterbarukan setiap negara memperebutkan sumber energi ini dan tidak jarang sumber energi ini menyebabkan sengketa antar negara, seperti yang terjadi antara Indonesia dan Malaysia di kawasan ambalat,kedua negara menghendaki Ambalat untuk masuk menjadi bagian dari wilayah masing-masing negara. Kepentingan strategis Indonesia di Ambalat adalah mempertahankan Ambalat sebagai hak berdaulat Republik Indonesia

\section{Kepentingan Pragmatis}

Ambalat sendiri merupakan kawasan yang sangat strategis bagi perekonomian Indonesia, Blok Ambalat secara strategis sangat penting karena potensi hydrocarbon yang dikandungnya dan potensi perikanan yang sangat produktif. Seperti yang dikutip dari Syafarudin usman dan Isnawita yang mengatakan bahwa kawasan Ambalat mempunyai banyak sumber daya alam seperti ikan,karang dan Migas (minyak dan gas bumi) kawasan ini diperkirakan memiliki sembilan cekungan dimana tiap cekungan diperkirakan memiliki 764 juta barel cadangan minyak dan 1,4 triliun kaki kubik cadangan gas, dengan kekayaan sumber daya alam yang dimiliki ini dapat menghasilkan kurang lebih US\$ 40 miliar. $^{19}$

Hal ini dapat dilihat semenjak Indonesia memberikan konsesi kepada perusahaan asing di blok ambalat, Berdasarkan eksplorasi yang dilakukan ENI Ambalat di lapangan Aster, nama tempat yang diberikan ENI di kawasan yang menjadi tempat penggalian, disebutkan bahwa terdapat lima sumur yang diperkirakan mengandung cadangan minyak 30.000-40.000 barel perhari, sedangkan di Ambalat Timur yang dipegang oleh Chevron, kandungan minyaknya

\footnotetext{
${ }^{18}$ Ibid., hal. 158

${ }^{19}$ Syafarudin Usman dan Isnawita, Op.Cit., hal.25.
} 


\section{Global Insigint Journal}

diperkirakan oleh BP Migas sebanyak 62 juta barel minyak dan 348 milar kaki kubik gas. ${ }^{20}$

Selanjutnya Bachrawi Sanusi juga menjelaskan bahwa sejak awal 1994 cadangan minyak bumi Indonesia mencapai 9.48 miliar barel sedangkan gas bumi mencapai $114,8 \mathrm{TSCF}^{21}$ Indonesia adalah salah satu negara yang terletak pada posisi silang yang strategis dan diapit oleh beberapa negara pasifik sehingga menjadikan Indonesia sebagai salah satu jalur perdagangan yang strategis. $^{22}$ Minyak dan gas bumi yang melimpah di Indonesia menurut Kholid Syerazi membuat Indonesia menerima pemasukan ekonomi yang luar biasa, kontribusi Minyak terhadap penerimaan negara sangat besar pada tahun 2007 penerimaan negara dari kegiatan hulu migas mencapai US\$ 23,7 miliar (kurang lebih 23,32 triliun), semenjak tahun 2002 penerimaan negara dari sektor hulu migas ini mengalami peningkatan yang rata-rata diperkirakan naik 35 persen per tahun, hal ini dipengaruhi oleh kenaikan harga minyak dunia sehingga memberikan keuntungan yang besar bagi Indonesia. ${ }^{23}$ Oleh karena itu Indonesia mempunyai kepentingan pragmatis yang besar di wilayah Ambalat, Indonesia akan terus berjuang untuk mendapatkan hak berdaulat di Ambalat.

\section{Usaha Pemerintah Indonesia Dalam Penyelesaian Ambalat}

Pemerintah Indonesia dalam mempertahankan Ambalat melakukan beberapa langkah dengan berbagai pendekatan dari sisi hukum dan politik seperti pengadaan perundingan bilateral dan pendekatan dari sisi kedekatan wilayah. Adapun pendekatan-pendekatan yang dilakukan akan dijelaskan lebih lanjut oleh penulis.

\footnotetext{
${ }^{20}$ Ibid., hal.36.

${ }^{21}$ Ibid., hal.53.

${ }^{22}$ Abdul Rivai Ras, "Geostrategi Indonesia”, Konflik Laut Cina Selatan dan Ketahanan Regional Asia Pasifik Sudut Pandang Indonesia, Jakarta : PT Rendino Putra Sejati, 2001, hal.24.

${ }^{23}$ Kholid Syerazi, Op.Cit., hal.6.
} 


\section{Pendekatan Secara Hukum}

Pemerintah Indonesia membuat Undang-Undang dan beberapa Peraturan Pemerintah (PP) segera setelah diakuinya Indonesia sebagai negara kepulauan, sebagai implementasi dari disahkan nya Indonesia oleh UNCLOS sebagai negara kepulauan pemerintah Indonesia mengeluarkan Undang Undang No.17 tahun 1985 tentang pengesahanUNCLOS $1982 .^{24}$

Pemerintah Indonesia juga mengeluarkan beberapa Peraturan Pemerintah (PP) untuk memperkuat UNCLOS 1982 seperti peraturan perundangan PP No 38 tahun 2002 tentang Daftar Koordinat Titik Titik Garis Pangkal Kepulauan Indonesia yang kini telah disempurnakan dengan PP No 37 tahun 2008, didalam PP tersebut Indonesia memiliki 195 titik dasar, 159 garis pangkal lurus, dan 32 garis pangkal normal termasuk didalamnya pengaturan garis pangkal kepulauan dari karang unarang. ${ }^{25}$ Dan berkaitan dengan sengketa Ambalat seperti yang dijelasakan oleh Koridatul Anissa pada diatas mengenai Ambalat bahwa jika garis pangkal ditarik dari karang Unarang maka Ambalat masih termasuk landas kontinen Indonesia karena jaraknya hanya 27 mil laut.

Selain undang-undang dan beberapa peraturan permerintah yang dikeluarkan untuk memperkuat Indonesia sebagai negara kepulauan serta sebagai implementasi hukum laut internasional (UNCLOS), pemerintah Indonesia berpegangan pada peraturan UNCLOS, di dalam UNCLOS disebutkan perbedaan antara negara pulau dan negara pantai. Pemerintah Indonesia tidak membawa masalah ini ke ICJ atau ke ASEAN, hal ini dipertimbangkan karena Indonesia dan Malaysia adalah negara yang tergabung dalam asosiasi negara yang disebut dengan ASEAN (Assosiation South East Asia Nation).

ASEAN mempunyai mekanisme penyelesaian sengketa antar anggotanya seperti TAC (Treaty Of Amity and Cooperation) yang diciptakan pada tahun 1976,

\footnotetext{
${ }^{24}$ Didik Mohammad Sodik, "Pengaturan Konvensi Hukum Laut 1982 Tentang Perairan Nasional dan Implementasinya di Indonesia", Hukum Laut Internasional dan Pengaturannya di Indonesia, Bandung:Refika Aditama, hal.17.

${ }^{25}$ Ibid., hal.51.
} 
didalam TAC menurut Hilton Tanama Putra dan Ek An Aqimudin terdapat prinsip dalam penyelesaian sengketa salah satunya adalah penyelesaian sengketa dan perselisihan secara damai. ${ }^{26}$ Untuk pengajuan suatu sengketa ke forum TAC maka harus melalui persetujuan kedua negara yang bersengketa.

Selain dari TAC mekanisme penyelesaian sengketa lainnya yang ada di ASEAN adalah Piagam ASEAN 2007. Menurut Hilton Tarnama Putra dan Eka An Aqimudin dalam piagam ASEAN 2007 berdasarkan pasal 22 ayat 1 menjelaskan prinsip-prinsip penyelesaian sengketa secara damai seperti negosiasi, dialog dan konsultasi. ${ }^{27}$

Prinsip-prinsip TAC dan Piagam ASEAN adalah pertimbangan Indonesia untuk tidak membawa sengketa Ambalat ke jalur hukum seperti MI, Pemerintah Indonesia sangat mengacu pada ketetapan UNCLOS bab IV dan diperkuat dengan pembuatan undang-undang nasional seperti Pasal 76 Unclos 1982 yang mengatur mengenai landas kontinen, pemerintah membuat undang -undang nasional untuk mengesahkan dengan UU No.1 th.1973 tentang Landas Kontinen Indonesia, Pasal 57 Unclos 1982 diperkuat dengan UU No.5 th. 1983 tentang ZEE Indonesia. ${ }^{28}$

\section{Pendekatan Secara Politik}

Pendekatan secara politik yang penulis akan jelaskan dalam bab ini berhubungan dengan national power (kekuatan nasional) suatu negara baik secara langsung maupun tidak langsung. Dengan pendekatan politik yang didasarkan national power maka suatu negara tidak akan mudah diintimidasi oleh pihak lawan. Dikaitkan dengan sengketa Ambalat, national power (kekuatan nasional) secara langsung adalah kualitas yang terdapat dalam pemerintah Indonesia seperti kualitas diplomat dan kualitas tim perunding yang nantinya akan menjadi ujung tombak dalam perundingan. Sedangkan national power yang tidak langsung adalah kekuatan militer Indonesia sebagai lembaga untuk mempertahankan wilayah Indonesia. Sengketa Ambalat bermula pada tahun 2005 dan mulai mereda

\footnotetext{
${ }^{26}$ Hilton Tanama Putra dan Eka An Aqimudin, Op.Cit., hal.43.

${ }^{27}$ Ibid., hal.109.

${ }^{28}$ Dikdik Mohammad Sodik, Op.Cit., hal.96.
} 
ketika kedua negara melakukan perundingan bilateral. Menurut Moh Zahirul Alim perundingan bilateral pertama diadakan di Bali, Indonesia pada 22-23 Maret 2005, kemudian di Langkawi, Malaysia pada 25 -26 May 2005, kemudian dilanjutkan di Jogjakarta, Indonesia 25-26 Juli 2005, Johor Baru, Malaysia 27-28 September 2005, dan terakhir di Palembang, Indonesia pada 2-3 November 2005. ${ }^{29}$ Perundingan yang dilakukan Indonesia dan Malaysia pada tahun 2005 menurut Ratna Shofi Inayati mengurusi tentang berbagai masalah yang tertunda, berikut adalah kutipannya :

"Pertemuan pada tahun 2005 tersebut mengurusi berbagai masalah yang tertunda seperti penentuan garis batas maritim kedua negara, garis landas kontinen serta garis batas Zona Ekonomi Ekslusif (ZEE) di Laut Sulawei, wilayah Selat Malaka, Selat Singapura dan perairan sekitar Pulau Natuna". ${ }^{30}$

Melihat perundingan pada tahun 2005 dan 2009, hasil yang dicapai belum maksimal karena belum adanya peraturan yang mengikat kedua negara secara hukum, pelanggaran-pelanggaran yang dilakukan TLDM Malaysia tetap meningkat dan pemerintah telah mengeluarkan 36 kali nota protes. Maka dalam hal ini, kapabilitas diplomat Indonesia masih perlu ditingkatkan lagi dan diharapkan agar diplomat Indonesia pada perundingan berikutnya dapat menekan pihak lawan untuk mempunyai kesepakatan yang mengikat bagi kedua negara.

Selain itu pemerintah Indonesia juga harus mempersiapkan team perunding yang handal untuk menyelesaikan masalah ini, tim perunding tersebut menurut Hikmahanto Juwana, Guru Besar Hukum Internasional pada Fakultas Hukum UI Jakarta, wajib memiliki keterampilan seperti instrumen hukum internasional, kasus-kasus yang pernah diputus terkait dengan penyelesaian

\footnotetext{
${ }^{29}$ Moh. Zahirul Alim, Op.Cit., hal.74.

${ }^{30}$ Ratna Shofi Inayati, Op.Cit., hal.60.
} 
sengketa wilayah dan juga mempunyai keterampilan untuk menelusuri berbagai bukti yang dapat menguatkan untuk memenangkan sengketa. ${ }^{31}$

\section{Pendekatan Secara Kedekatan Wilayah}

Untuk langkah penyelesaian menggunakan pendekatan wilayah, sebelumnya perlu diketahui terlebih dahulu definisi mengenai Kedaulatan (soverignity) dan Hak Berdaulat (sovereignity Right), karena dalam kasus Ambalat ini, masih banyak masyarakat yang salah paham antara konflik kedaulatan dan konflik hak berdaulat.

I Made Arsana mengatakan, “Ambalat bukanlah pulau (wilayah darat) melainkan wilayah maritim yang berada di luar laut territorial Indonesia, wilayah maritim yang sudah berada lebih dari 12 mil laut dari garis pangkal (laut territorial). Maka hal ini sudah bukan termasuk kedaulatan Indonesia lagi melainkan hak berdaulat."32 Berkaitan dengan kedekatan wilayah dengan Ambalat, menurut penulis Indonesia mempunyai jarak yang lebih dekat dengan Ambalat daripada Malaysia, hal ini disebabkan oleh perbedaan penarikan garis pangkal antar kedua Negara.

Menurut Khoridatul Anissa, karena Malaysia diputuskan UNCLOS sebagai negara pantai maka hanya dapat menarik garis pangkalnya sejauh 12 mil dari wilayah Sabah sehingga 200 mil laut dari garis pangkal untuk zona ekonomi ekslusifnya, dengan pengukuran ini maka jarak Malaysia dengan wilayah Ambalat adalah sejauh 42 mil laut. Sedangkan Indonesia, sesuai dengan ketentuan UNCLOS bahwa Indonesia dapat menarik garis pangkal dari pulau terluar Indonesia, dalam hal ini penarikan dilakukan dari Karang Unarang yang mejadi basepoint baru Indonesia setelah Sipadan Ligitan menjadi milik Malaysia. Sehingga jika diukur dari penarikan garis pangkal hingga batas terluar Zona Ekonomi Ekslusif yang dimiliki Indonesia, maka Indonesia hanya berjarak 27 mil

\footnotetext{
${ }^{31}$ Hikmahanto Juwana, "Penyelesaian Damai Ambalat", KOMPAS, diunduh dari http://perpustakaan.bappenas.go.id/lontar/opac/themes/bappenas4/templateDetail.jsp?id=38814 \&lokasi=lokal, diakses pada 03 Agustus 2013.

32 Ibid.,hal.155.
} 
laut dari $\mathrm{Ambalat}^{33}$ jarak ini lebih dekat dari pada jarak yang dimiliki Malaysia ke Ambalat.

Jika ditinjau dari cara pengukuran diatas maka Indonesia lebih berhak untuk memiliki Ambalat daripada Malaysia, selain itu Indonesia juga telah melakukan penguasaan efektif di kawasan sekitar Ambalat semenjak tahun 1960an, Indonesia telah melakukan konsesi minyak kepada beberapa perusahaan asing dan hal ini diketahui oleh Malaysia namun Malaysia tidak memprotes tindakan Indonesia, hal ini secara tidak langsung bahwa Malaysia mengakui Ambalat adalah bagian dari Indonesia. Selain itu ahli hukum laut internasional Hasyim Djalal mengungkapkan bahwa Ambalat adalah kelanjutan alamiah dari Kalimantan Timur. Berikut adalah kutipan mengenai ungkapan Hasyim Djalal :

"Blok Ambalat dan Ambalat Timur yang di klaim Malaysia merupakan kelanjutan alamiahdari daratan Kalimantan Timur. Antara Sabah, Malaysia dan kedua blok tersebut terdapat laut dalam yang tidak mungkin bisa dikatakan bahwa kedua blok tersebut merupakan kelanjutan alamuag Sabah. Kelanjutan alamiah dari daratan merupakan kewenangan negara atas wilayah laut yang tercantum dalam Konvensi Hukum Laut Internasional 1982."34

Berdasarkan pernyataan dari Hasyim Djalal yang mengatakan bahwa Ambalat adalah kelanjutan alamiah dari wilayah daratan Kalimantan Timur, maka Indonesia juga bisa menggunakan pengukuran dengan Landas Kontinen. Landas Kontinen menurut UNCLOS 1982 Pasal 76 ayat 1 memberikan batasan bahwa suatu negara dapat menarik landas kontinen 200 mil laut hingga 350 mil laut sepanjang kelanjutan alamiah dari wilayah daratannya. Pemerintah Indonesia juga bisa menggunakan cara pengukuran tersebut untuk menghitung kedekatan

\footnotetext{
${ }^{33}$ Peta Nasional Indonesia Nomor 59, Skala 1:200.000, diterbitkan oleh Dinas Hidro Oseanografi TNI AL dalam Khoridatul Anissa., Op.Cit., hal.204./

${ }^{34}$ Kompas, "Ambalat Lanjutan Alamiah Kaltim",diunduh dari http://www.kompas.co.id/kompascetak/0503/09/utama/1612098.html, diakses pada 5 Agustus 2013.
} 
Indonesia dengan wilayah Ambalat, berdasarkan pengukuran landas kontinen maka Ambalat masih termasuk bagian wilayah Indonesia.

\section{Perkembangan Dalam Penyelesaian Sengketa Ambalat}

Perundingan dinilai Indonesia merupakan jalan yang elegan dan juga murah dalam menghadapi masalah perbatasan, sehingga pertimbangan Indonesia tidak membawa masalah ini ke ICJ (International Court Of Justice Mahkamah Internasional) selain kedua negara tergabung dalam ASEAN dan mempunyai prinsip-prinsip ASEAN yang dipegang oleh kedua negara, hal ini juga merupakan salah satu alasan Indonesia tidak membawa masalah ini ke Mahkamah Internasional. Perundingan- perundingan yang diadakan oleh Indonesia dan Malaysia selama sengketa Ambalat berlangsung telah menghasilkan beberapa kemajuan seperti yang diungkapkan oleh mantan juru bicara deplu, Yuri O Thamrin pada press briefing tanggal 30 september 2005 :

"Mengenai pertemuan keempat batas maritim RI dan Malaysia, tanggal 27- 28 September 2005 ada kemajuan bahwa kedua belah pihak sepakat untuk menggunakan UNCLOS 1982 sebagai rujukan dan sepakat untuk membentuk kelompok kerja teknis." 35

Selain itu menurut Kementerian Luar Negeri Indonesia dan Malaysia sendiri telah melakukan perundingan batas maritim mengenai laut teritorial, zona ekonomi ekslusif, landas kontinen di beberapa segemen laut seperti Selat Malaka, Selat Malaka Selatan, Laut China Selatan, Selat Singapura dan Laut Sulawesi semenjak tahun 2005. ${ }^{36}$ Pemerintah kedua negara berkomitmen untuk meningkatkan intensitas perundingan batas maritim sehingga dapat menghasilkan kemajuan signifikan dalam penyelesaian batas maritim antara kedua negara ini.

\footnotetext{
${ }^{35}$ Kementerian Luar Negeri, "Pokok-Pokok Press Briefing Juru Bicara Deplu, Yuri O Thamrin pada 30 September 2005", diunduh dari http://www.deplu.go.id/Pages/PressBriefing. aspx?IDP=30, diakses pada 12 Agustus 2013.

${ }^{36}$ Kementerian Luar Negeri, "Perundingan Tingkat Teknis Perbatasan Maritim RI - Malaysia ke16, Kuantan, Malaysia 13-14 Oktober 2010", diunduh dari http://www.deplu.go.id/Pages/ PressRelease. aspx?IDP=1011, diakses pada 17 Agustus 2013.
} 
Pertemuan kedua negara di Kinabalu, Malaysia tanggal 20 July 2009 juga membicarakan penyelesaian batas maritim di kawasan Ambalat, pertemuan kali ini mencapai kemajuan yang cukup pesat walaupun bukan kemajuan dalam kesepakatan batas maritim kedua negara di Ambalat, kemajuan yang dimaksud dalam pertemuan ini adalah team perunding baru dari Malaysia yang cukup membantu kelancaraan proses perundingan tersebut.

Kedua negara juga bersepakat mempercepat pertemuan penyelsaian perbatasan laut yang masih menjadi sengketa termasuk Ambalat dan akan mengadakan empat kali pertemuan hingga desember 2010, kesepakatan ini merupakan hasil pertemuan pada Joint Commission for Bilateral Cooperation (JCBC) RI-Malaysia di Kinabalu, Malaysia. ${ }^{37}$ Kemudian pada tanggal 28 September 2010 pagi waktu Indonesia di New York, Menteri Luar Negeri Indonesia Marty Natalegawa dan Menteri Luar Negeri Malaysia Datuk Seri Anifah Aman bertemu di sela-sela sidang ke-65 Majelis Umum Perserikatan Bangsa-Bangsa. Dalam pertemuan ini kedua Menteri Luar Negeri sepakat untuk memprioritaskan perundingan perbatasan laut Indonesia dan Malaysia di wilayah Selat Singapura dan Laut Sulawesi. ${ }^{38}$

Dalam pertemuan kedua Menteri Luar Negeri tersebut juga dicapai kesepakatan dalam membahas sengketa yang terjadi bahwa kedua negara sepakat untuk membentuk forum baru yang dinamai Forum Pengelolalaan Batas dan forum ini akan melibatkan berbagai kementerian-kementerian dari kedua negara. ${ }^{39}$ Hal ini akan mempermudah proses perundingan batas maritim Indonesia dan Malaysia.

Menurut data dari Kementerian Pertahanan Republik Indonesia, Indonesia dan Malaysia telah melakukan perundingan teknis batas maritim dari tahun 2005, dan hingga tahun 2012 sudah memasuki putaran ke 22 di Kota Kinabalu Malaysia

\footnotetext{
${ }^{37}$ Antaranews, "Sengketa Perbatasan Diselesaikan Cepat", Suara Merdeka, diunduh dari http://www.suaramerdeka.com/v2/index.php/read/cetak/2010/09/07/123052/Sengketa-PerbatasanDiselesaikan-Cepat, diakses pada 16 Agustus 2013

${ }^{38}$ Tempo Interaktif, “ Bahas Perbatasan, Malaysia -Indonesia Bertemu di New York”, diunduh dari http://www.tempo.co/read/news/2010/09/28/078281012/Bahas-Perbatasan-Malaysia--Indonesia-Bertemu-di-New-York, diakses pada 17 Agustus 2013

${ }^{39}$ Ibid.
} 
yang diadakan pada tanggal 9-11 Mei 2012, adapun hasil perundingan yang dicapai dalam putaran ke-22 adalah sebagai berikut :

"Khusus untuk perundingan batas maritim di sekitar blok Ambalat Laut Sulawesi (laut territorial, zona ekonomi eksklusif dan landas kontinen), sesuai kesepakatan kedua belah pihak sampai saat ini baru membicarakan mengenai batas laut teritorial di sekitar perairan Pulau Sebatik... ${ }^{40}$

Merujuk hasil perundingan yang didapat di putaran ke-22 tersebut maka dapat disimpulkan bahwa belum terdapat kesepakatan antar kedua negara mengenai ZEE dan Landas Kontinen blok Ambalat, perundingan masih berlanjut untuk hingga saat ini. Perundingan untuk membahas batas maritim memerlukan jangka waktu yang lama, Namun dalam kasus Ambalat kedua negara tetap bersepakat untuk mengintensifkan perundingan bilateral dan tidak membawa sengketa ini ke ranah hokum.

\section{PENUTUP}

Dalam penyelesaian sengketa ini Pemerintah Indonesia mempertimbangkan bahwa Indonesia dan Malaysia merupakan negara yang tergabung dalam ASEAN (Association of South East Asia Nations) dimana dalam ketentuan ASEAN terdapat prinsip-prinsip dalam penyelesian sengketa. Pemerintah Indonesia mengacu pada prinsip TAC (Treaty Of Amity and Cooperation) yang diciptakan pada tahun 1976, di dalam TAC disebutkan salah satu prinsip penyelesaian sengketa adalah penyelesaian dilakukan secara damai, selain itu ASEAN juga mempunyai prinsip yang disebut dengan Piagam ASEAN. Piagam ASEAN sendiri tercipta pada tahun 2007 dimana dalam Piagam ASEAN pasal 22 ayat 1 menjelaskan prinsip-prinsip penyelesian sengketa secara damai seperti negosiasi, dialog, dan konsultasi.

\footnotetext{
${ }^{40}$ Kementerian Pertahanan Republik Indonesia, "Perbatasan Maritim Indonesia”, diunduh dari http://strahan.kemhan.go.id/web/produk/perbatasan.pdf, diakses pada 21 Agustus 2013.
} 
Adapun langkah-langkah yang dilakukan oleh Indonesia untuk menyelesaikan sengketa Ambalat ini adalah dengan melakukan beberapa pendekatan seperti pendekatan secara hukum, pendekatan secara politik dan pendekatan secara kedekatan wilayah.

Pendekatan secara hukum dilakukan pemerintah Indonesia dengan membuat undang-undang dan beberapa Peraturan Pemerintah (PP) sebagai implementasi dari disahkannya Indonesia sebagai negara kepulauan oleh UNCLOS 1982, tepat setelah diresmikan Indonesia sebagai negara kepulauan. Pemerintah mengeluarkan Undang Undang No.17 tahun 1985 tentang pengesahan UNCLOS 1982 kemudian mengeluarkan beberapa Peraturan Pemerintah (PP) untuk memperkuat UNCLOS 1982 seperti peraturan perundangan PP No 38 tahun 2002 tentang Daftar Koordinat Titik Titik Garis Pangkal Kepulauan Indonesia yang kini telah disempurnakan dengan PP No 37 tahun 2008.

Pendekatan secara politik dilakukan Indonesia dengan cara meningkatkan perundingan bilateral antar kedua belah pihak. Selain itu pemerintah Indonesia juga mempersiapkan team perunding dan diplomat-diplomat yang ahli dalam bidangnya untuk meyelesaikan sengketa Ambalat. Sedangkan pendekatan yang terkahir digunakan adalah pendekatan secara wilayah, cara ini digunakan untuk mengukur kedekatan wilayah Ambalat ke salah satu negara. Jika diukur dari garis pangkal (baseline) masing-masing negara maka Malaysia berjarak 42 mil laut sedangkan Indonesia hanya 27 mil laut dari garis pangkal ke wilayah Ambalat. Jika dilihat dari pengukuran ini tentu Indonesia lebih berhak atas hak berdaulat di Ambalat.

Perundingan bilateral antar kedua negara hingga saat ini masih berlangsung. Menurut data dari Kementerian Pertahanan, perundingan teknis batas maritim kedua negara di Laut Sulawesi telah memasuki putaran ke-22 namun belum ada kesepakatan mengenai batas Landas Kontinen dan Zona Ekonomi Ekslusif di Ambalat. 


\section{Saran}

Indonesia harus lebih berhati-hati dalam penyelesaian sengketa Ambalat sehingga tidak terulang kejadian seperti Sipadan dan Ligitan untuk kedua kalinya. Adapun langkah -langkah yang dapat diambil yaitu mempersiapkan bukti dan diplomasi yang kuat bahwa Ambalat adalah bagian dari hak berdaulat Republik Indonesia, selain itu peningkatan kapasitas diplomat dan team perundingan juga harus lebih diperhatikan.

Pemerintah Indonesia juga perlu meningkatkan penjagaan di kawasan perbatasan dengan menempatkan TNI AL dan TNI AU, selain itu Indonesia juga harus tegas terhadap pelanggaran-pelanggaran yaang dilakukan oleh Malaysia. Pemerintah Indonesia baik Presiden, Kementerian Luar Negeri, Kementerian Pertahanan, dan seluruh pemerintah yang bertanggung jawab wajib mengintensifkan perundingan bilateral dengan Malaysia terutama masalah perbatasan maritim salah satunya Ambalat sehingga sengketa ini tidak berlarutlarut dan mendapatkan kesepakatan yang mengikat secara hukum bagi kedua belah pihak.

\section{DAFTAR PUSTAKA}

Annisa, Khoridatul (2009) . Malaysia Macan Asia : Ekonomi, Politik, SosialBudaya dan Dinamika Hubungannya Dengan Indonesia. Yogyakarta : Garasi

Arsana,I Made Andi (2007).Batas Maritim Antarnegara.Yogyakarta:Gajah Mada University Press

Aqimudin,Eka An,Hilton ,Tarnama Putra(2011).Mekanisme Penyelesaian Sengketa di Asean.Yogyakarta:Graha Ilmu

Alim,Moh Zahirul.Ganyang Malaysia Mengapa Tidak Ampuh Lagi:FPDA dalam Konstelasi Konflik Indonesia-Malaysia.Yogyakarta:Aswaja Presindo 
Djalal,Dino Patti(1996). The Geopolitics Of Indonesia's Maritime Territorial Policy. Jakarta:CSIS

Dam,Syamsumar(2010). Politik Kelautan.Jakarta:Bumi Aksara

Faisal,Sanapiah (1990).Penelitian Kualitatif : Dasar-dasar dan Aplikasi.Malang: Yayasan Asih Asah Asuh

Hayati, Sri,Ahmad Yani(2007) . Geografi Politik. Bandung : PT. Refika Aditama

Isnawita,Syafaruddin,Usman(2009).Heboh Ambalat:Ternyata Malaysia Ingin Merebut Sumber Minyak Indonesia. Yogyakarta:Narasi

Mas'oed, Mohtar (1990). Ilmu Hubungan Internasional : Disiplin dan Metodologi. Jakarta : LP3ES.

Madu, Ludiro., Aryanta, Nugraha., \&Nikolaus, Loy Fauzan (2010). Mengelola Perbatasan Indonesia di Dunia Tanpa Batas. Yogyakarta : Graha Ilmu

Moleong,Lexy.J.(1990).Metodologi Penelitian Kualitatif.Bandung: PT Remaja Rosdakarya

Morgenthau,Hans.,J(2006).Politik Antarbangsa.Jakarta:Yayasan Pustaka Obor Indonesia

Purwanto,Wawan H (2010). Panas Dingin Hubungan Indonesia - Malaysia. Jakarta : CMB Press

Rezahsyah, Teuku (2011).17 Bom Waktu Hubungan Indonesia - Malaysia. Bandung: Humaniora - Anggota IKAPI

Ras,Abdul Rivai(2001). Konflik Laut Cina Selatan dan Ketahanan Regional Asia Pasifik Sudut Pandang Indonesia. Jakarta : PT Rendino Putra Sejati

Sodik, Didik Mohammad (2011). Hukum Laut Internasional dan Pengaturannya di Indonesia. Bandung: PT. Refika Aditama

Sukanta (2007). Konflik Tak Berujung : Mengupas Konflik dan Interdependensi Mesir - Sudan dalam Perspektif Teori Hubungan Internasional. Jakarta Selatan : TERAJU 
Syeirazi,M Kholid(2009). Di Bawah Bendera Asing.Jakarta:Pustaka

Sanusi,Bachrawi (2004). Potensi Ekonomi Migas Indonesia. Jakarta: PT.Rineka Cipta

Umar,Musni(2011). Soft Power Approach Indonesia - Malaysia. Jakarta:INSED (Institute for Social Empowerment and Democracy)

Wirawan (2010).Konflik dan Manajemen Konflik:Teori,Aplikasi,dan Penelitian. Jakarta:Salemba Humanika

TESIS :

Sutrisno,Heri,'Penataan Sistem Keamana Laut Indonesia Dalam Perspektif Ketahanan Nasional,’Tesis,Jakarta:UI,2006.

\section{WEBSITE :}

Ahmad,Safwan,2009, Soal Ambalat:Menhan Malaysia akan Gunakan Jalur Diplomatik,http://www.tempo.co/read/news/2009/06/03/118179829/SoalAmbalat-Menhan-Malaysia-Akan-Gunakan-Jalur-Diplomatik, diakses pada 28 May 2013

Antaranews,2010,Sengketa Perbatasan Diselesaikan Cepat, http://www.suaramerdeka.com/v2/index.php/read/cetak/2010/09/07/12305 2/Sengketa-Perbatasan-Diselesaikan-Cepat, diakses pada 16 Agustus 2013

Damayanti,Ninin,2009, KSAL : Tahun 2007, Malaysia Masuk Batas Blok Ambalat 76Kali, http://www.tempo.co/read/news/2009/06/03/078179827/KSAL--Tahun2007-Malaysia-Masuk-Batas-Blok-Ambalat-76-Kali, diakses pada 28 May 2013

Darlis,2009, Indonesia Latihan Perang:Malaysia Perbanyak Pasukan, http://www.tempo.co/read/news/2009/06/08/063180520/IndonesiaLatihan-Perang-Malaysia-Perbanyak-Pasukan, 28 May 2013

Gemilang,Mirza,2011,Hari Nusantara 2011 : Negara kepulauan diakui Dunia,http://hankam.kompasiana.com/2011/09/12/hari-nusantara-2011- 


\section{Global Insight Journal}

negara-kepulauan-diakui-dunia-395067.html. Diakses pada 17 Maret 2013

Ima,2009, RI Peringatkan Malaysia Hormati Perundingan Ambalat, http://lipsus.kompas.com/topikpilihanlist/2133/1/100.hari.jokowibasuki/read/xml/2009/06/06/23095467/RI.Peringatkan.Malaysia.Hormati. Perundingan.Ambalat, diakses pada 02 April 2013

Juwana,Hikmahanto,2005, Penyelesaian Damai Ambalat, http://perpustakaan.bappenas.go.id/lontar/opac/themes/bappenas4/templa teDetail.jsp?id=38814\&lokasi=lokal, diakses pada 03 Agustus 2013

Kompas,2009, Daulat Ambalat Itu Harga Mati, http://regional.kompas.com/read/2009/06/03/05431824/Daulat.Ambalat.It u.Harga.Mati, diakses pada 28 Juli 2013

Kompas,2005, Rencana Kerja Untuk Solusi Ambalat Disusun, http://perpustakaan.bappenas.go.id/lontar/opac/themes/bappenas4/templa teDetail.jsp? $i d=38813$ \&lokasi=lokal, diakses pada 28 Juli 2013

Kompas,2009, Ambalat Lanjutan Alamiah Kaltim, http://www.kompas.co.id/kompas-cetak/0503/09/utama/1612098.htm, diakses pada 05 Agustus 2013

Kementrian Luar Negeri,2005, Pokok-Pokok Press Briefing Juru Bicara Deplu, Yuri O Thamrin pada 30 September 2005, http://www.deplu.go.id/Pages/PressBriefing.aspx?IDP=30, diakses pada 12 Agustus 2013

Kementrian Luar Negeri, Penyimpanan Naskah Perjanjian InternasionalPerbatasan, http://naskahperjanjian.kemlu.go.id/?idtreaty/section/page, diakses pada 13 Agustus 2013

Kementrian Luar Negeri,2010, Perundingan Tingkat Teknis Perbatasan Maritim RI - Malaysia ke-16, Kuantan, Malaysia 13-14 Oktober 2010, http://www.deplu.go.id/Pages/PressRelease.aspx?IDP=1011, diakses pada 17 Agustus 2013 
Kementrian Pertahanan Republik Indonesia, Perbatasan Maritim Indonesia, diunduh dari http://strahan.kemhan.go.id/web/produk/perbatasan.pdf, diakses pada 21 Agustus 2013

Mulyadi,Agus,2012, TNI Tambah Pasukan di Perbatasan, http://regional.kompas.com/read/2012/10/05/11411963/TNI.Tambah.Pasu kan.di.Perbatasan, diakses pada 08 Juni 2013

Manan,Abdul,2005,Ambalat Tetap Bagian Wilayah Indonesia, http://www.tempo.co/read/news/2005/03/23/05558490/Ambalat-TetapBagian-Wilayah-Indonesia, diakses pada 13 July 2013

Pardosi,Ishak,2013,95 Persen Migas Indonesia Dikuasai Korporasi Asing, http://gagasanriau.com/95-persen-migas-indonesia-dikuasai-korporasiasing/, diakses pada 09 May 2013

Rochmi,Nur,2009,Sengketa Ambalat, SBY Pilih Upaya Diplomasi.,http://www.tempo.co/read/news/2009/06/01/063179075/Sengk eta-Ambalat-SBY-Pilih-Upaya-Diplomasi,diakses pada 28 May 2013

Raharjo,Sandy Nur Ikhfal,2011, Pekerjaan Rumah Perbatasan Indonesia Malaysia, http://www.politik.lipi.go.id/in/kolom/politik-internasional/526pekerjaan-rumah-perbatasan-indonesia-malaysia.html, diakses pada 03 Agustus 2013

Subagja, Raden Terry,2009, Malaysia atas Blok Ambalat. http://radenterrysubagja.wordpress.com/category/global-issues/. Diakses pada 24 January 2013

Simanjuntak,Arnold,2009,Arif H. Oegroseno: Peta Malaysia Diprotes Banyak Negara, http://www.tempo.co/read/news/2009/06/22/063183050/Arif-HOegroseno-Peta-Malaysia-Diprotes-Banyak-Negara,diakses pada 10 February 2013

Suhartono,2009, Soal Ambalat Presiden Tidak Akan Kompromi, http://nasional.kompas.com/read/2009/06/02/09035638/Soal.Ambalat..Pre siden.Tidak.Akan.Kompromi, diakses pada 08 Juni 2013 
Suryanto,2009, Menlu : Perundingan Ambalat Capai Kemajuan, http://www.antaranews.com/berita/152210/menlu-perundingan-ambalatcapai-kemajuan, diakses pada 17 Agustus 2013

Suara Merdeka,2009,Perundingan Ambalat Alami Kemajuan, http://suaramerdeka.com/v1/index.php/read/news/2009/08/25/35118 diakses pada 04 Aug 2013

Tabloid Diplomasi,2009,Sikap Pemerintah Tegas Untuk Ambalat, http://www.tabloiddiplomasi.org/previous-isuue/36-juni-2009/92-sikappemerintah-tegas-untuk-ambalat.html, diakses pada 03 Agustus 2013

Tempo Interaktif, 2010. Bahas Perbatasan, Malaysia -Indonesia Bertemu di New York",http://www.tempo.co/read/news/2010/09/28/078281012/BahasPerbatasan-Malaysia---Indonesia-Bertemu-di-New-York, diakses pada 17 Agustus 2013

Tabloid Diplomasi,2013,Permasalahan di Perbatasan RI, http://www.tabloiddiplomasi.org/previous-isuue/183-diplomasi-februari2013/1598-permasalahan-di-perbatasan-ri.html, diakses pada 17 Agustus 2013

Wibisono,SG.,2009, Tujuh Kapal Perang Terus Pantau Ambalat, http://www.tempo.co/read/news/2009/08/04/078190604/Tujuh-KapalPerang-Terus-Pantau-Ambalat, diakses pada 08 Juni 2013 